\title{
Pharmacotherapy and analysis of gaseous mediators in hypertensive patients*
}

\author{
Farmacoterapia e análise de mediadores gasosos em pacientes hipertensos \\ Farmacoterapia y análisis de mediadores gaseosos en pacientes hipertensos
}

Letícia Palota Eid ${ }^{1}$, Renato Nery Soriano², Marcelo Eduardo Batalhão ${ }^{3}$, Lais Palotta Balderrama ${ }^{4}$, Evelin Capellari Carnio ${ }^{5}$

\footnotetext{
* Extracted from the thesis "Farmacoterapia e análise de mediadores gasosos em pacientes hipertensos"' School of Nursing of Ribeirão Preto, University of São Paulo, 2014.

${ }^{1} \mathrm{PhD}$, School of Nursing of Ribeirão Preto, University of São Paulo, Ribeirão Preto, SP, Brasil.

${ }^{2} \mathrm{PhD}$, Federal University of Juiz de Fora, Juiz de Fora, MG, Brazil.

${ }^{3}$ Specialist in laboratory Physiology, School of Nursing of Ribeirão Preto, University of São Paulo.

${ }^{4}$ Public Health Graduate Student, Medical College of São José do Rio Preto, São José do Rio Preto, SP, Brazil.

${ }^{5}$ Associate Professor, Department of General and Specialized Nursing, School of Nursing of Ribeirão Preto, University of São Paulo, Ribeirão Preto, SP, Brazil.
}

\begin{abstract}
Objective: To evaluate the effect of using antihypertensive classes of drugs of the calcium channel antagonists and inhibitors of angiotensin-converting enzyme in plasma concentrations of hydrogen sulfide and nitric oxide in patients with hypertension. Methods: Cross-sectional study with quantitative approach conducted with hypertensive patients in use of antihypertensive classes of drugs: angiotensin-converting enzyme inhibitors or calcium channel antagonists. Results: It was found that the concentration of plasma nitric oxide was significantly higher in hypertensive patients that were in use of angiotensin-converting enzyme inhibitors $(p<0.03)$ and the hydrogen sulphide concentration was significantly higher in hypertensive plasma in use of calcium channel antagonists $(p<0.002)$. Conclusion: The findings suggest that these medications have as additional action mechanism the improvement of endothelial dysfunction by elevate plasma levels of vasodilatory substances.
\end{abstract}

\section{DESCRIPTORS}

Hypertension; Nitric Oxide; Hydrogen Sulfide; Antihypertensive Agents.

\section{Correspondence Addressed to} Letícia Palota Eid

Rua Luciano Lopes da Silva, 236 Alto da Vila Pati

CEP 14960-000 - Novo Horizonte, SP, Brazil E-mail: Ipalota@usp.br 


\section{INTRODUCTION}

The systemic arterial hypertension (SAH) is a common cardiovascular disease and the main risk factor for cerebrovascular accident $(\mathrm{CVA})$ or heart diseases ${ }^{(1)}$. In the United States of America, the prevalence rate of $\mathrm{SAH}$ are approximately $40 \%$ in adults over 20 years, being almost equal between men and women. Among adults with hypertension, $80 \%$ know their condition, $71 \%$ use antihypertensive drugs and only $48 \%$ of those who are aware of his/her illness have controlled blood pressure ${ }^{(2)}$.

Among the pathophysiological mechanisms of SAH, we include the role of the vascular endothelium. Endothelial cells play a key role in the regulation of vascular tone through the synthesis and release of relaxation and contraction factors. Nitric oxide (NO) is considered the key molecule involved in cardiovascular homeostasis ${ }^{(3)}$. A recent study has provided evidence to support the premise that the hydrogen sulphide $\left(\mathrm{H}_{2} \mathrm{~S}\right)$ is an endothelium-derived relaxing factor ${ }^{(4)}$. In general, it can be affirmed that the $\mathrm{H}_{2} \mathrm{~S}$ is a vasodilator substance capable of inducing an antihypertensive effect ${ }^{(5)}$.

With regard to SAH treatment, in a meta-analysis of 147 randomized studies, the authors found that in patients receiving treatment with antihypertensive medications there was a $22 \%$ reduction in coronary heart disease and a $41 \%$ reduction in $\mathrm{CVA}^{(6)}$, what demonstrates its great importance in reducing cardiovascular morbidity and mortality.

Considering the mechanism of knowledge of antihypertensive drugs' action, as well as gaseous mediators and their physiological and pathophysiological processes, it is relevant to the training of nurses in various specialties, the present study aimed to compare plasma concentrations of gaseous mediators nitric oxide $(\mathrm{NO})$ and hydrogen sulphide $\left(\mathrm{H}_{2} \mathrm{~S}\right)$ and check if there are associations between these mediators in hypertensive patients treated with calcium channel antagonists (CCA) and angiotensin-converting enzyme inhibitors (ACE inhibitor).

\section{METHOD}

Cross-sectional study, with a quantitative approach, conducted in a health unit located in a countryside city in the State of Sao Paulo, in the period from February to November 2013. We included patients with medical diagnosis of hypertension, antihypertensive monotherapy for more than five years, being the medication belonging to the classes of drugs: calcium channel antagonists or inhibitors of angiotensin-converting enzyme. The name of these patients were identified by a report in a software from the Pharmacy in the health unit, which generates patients' reports according to drug class in use.

When they were attended at the Health Unit for a clinical consultation, patients were asked to participate as subjects of research, moment when they received detailed orientation about the objectives and procedures to be performed.

The criteria adopted for exclusion were: age below 18 years, patients with terminal stage disease, like neoplasms or Aids and patients who were receiving other antihypertensive classes of drug not belonging to the calcium channel antagonists or inhibitors of angiotensin-converting enzyme.

A total of 36 participants were selected according to the inclusion and exclusion criteria, of these, 16 used antihypertensive drugs in the class of calcium channel antagonists and 20 used antihypertensive drugs in the class of angiotensin-converting enzyme inhibitors.

Initially the patients attended a nursing consultation, where they filled in a questionnaire containing general identification data (age, gender and skin color) and the names of the medications in use. The blood collection was scheduled and orientation was provided on the preparation for the procedure.

Venipuncture is a complex procedure, which requires knowledge and skill. The recommendations followed the standards of the Clinical and Laboratory Standards Institute (CLSI). The CLSI is an international, interdisciplinary, non-profit, recognized worldwide institute by promoting the development and use of voluntary standards and guidelines in the context of health care ${ }^{(7)}$.

The blood sample collection for carrying out the laboratory tests was performed after the consent of the patients. We collected from each individual $10 \mathrm{ml}$ of blood in tube containing $0.5 \mathrm{ml}$ of heparin for determination of hydrogen sulfide and nitrate plasma levels after fasting for 12 hours.

Laboratory testing of these samples was divided in two steps, the first carried out by centrifuge lab accredited by the Municipal Health Secretariat - Unified Health System (SUS), and the second step was conducted in the laboratory of Physiology of Nursing School of Ribeirao Preto (USP).

First step - Laboratory accredited by the Municipal Health Secretariat - Unified Health System (SUS). Samples were centrifuged at the Laboratory accredited by the Municipal Health Secretariat, at $3000 \mathrm{rpm}$ for 20 minutes, immediately after the collection has been made, for separation of the plasma, which was stored at $-70^{\circ} \mathrm{C}$. According to the Brazilian Society of Pathology ${ }^{(7)}$, the time between collection and centrifugation of the blood should not exceed one hour. These samples were carried in coolers with ice and thermometer for the laboratory of Physiology of the School of Nursing of Ribeirao Preto (USP), in a period of an hour and a half, where we conducted the next step, the determination of hydrogen sulphide and nitrate levels.

Second step - Laboratory of Physiology of the School of Nursing of Ribeirao Preto (USP). Dosage of $\mathrm{H}_{2} \mathrm{~S}$-every sample of $200 \mu$ l of plasma was added $20 \mu$ of L-cysteine $10 \mathrm{mM}, 20 \mu \mathrm{l}$ of pyridoxal 5 -phosphatase and $30 \mu \mathrm{l}$ of PBS incubated for 2 hours at $37^{\circ} \mathrm{C}$. Zinc acetate $(1 \% 100 \mu \mathrm{l})$ was then added followed by the addition of trichloroacetic acid $(10 \%(\mathrm{w} / \mathrm{v}) / 100 \mu \mathrm{l})$ to precipitate the protein and thus stop the reaction. After new centrifugation $50 \mu \mathrm{l}$ of $\mathrm{N}$-dimethyl sulfate-p-phenilenediamina $20 \mathrm{mM}$ was added followed by $50 \mu \mathrm{FeCl} 30 \mathrm{mM}$. A sample of the supernatant $(50 \mu \mathrm{l})$ was measured by spectrophotometry wavelength of $670 \mathrm{~nm}$. The $\mathrm{H}_{2} \mathrm{~S}$ concentration of each sample was calculated from a calibration curve of $100-0.1 \mu \mathrm{g} / \mathrm{ml} \mathrm{NaHS}$. All reagents used were purchased from Sigma (Sigma Chemical Co., St. Louis, MO, USA). For the measurement of the plasma NO, 
$\mathrm{NO}$ /ozone chemiluminescence technique was used. The nitrate concentration in plasma was measured using $5 \mu \mathrm{L}$ of sample injected in a reaction vessel containing a reducing agent $\left(0.8 \%\right.$ of vanadium chloride in $1 \mathrm{~N}$ of $\mathrm{HCl}$ to $\left.95^{\circ} \mathrm{C}\right)$ that converts the nitrate in $\mathrm{NO}$, in equimolares amounts. The NO was dredged using helium gas, to the chamber of the chemiluminescence Sievers NO Analyzer (Sievers ${ }^{\circledR}$ Nitric Oxide Analyzer 280 (GE Analytical Instruments, Boulder, CO. USA).

Data were analyzed using the analysis of variance (ANOVA) - Correction Test - for repeated measures and Tukey test for multiple comparisons of means. The results were presented as means and standard errors from mean (SEM). Differences were considered statistically significant at $\mathrm{p}<0.05$.

The study followed the aspects contained in Resolution 466/12 and the research project was approved by Ethics Committee of the College of Medicine of Sao Jose do Rio Preto (FAMERP), with the approval number 189.871/12.

\section{RESULTS}

A total of 36 subjects with hypertension participated in the study, using antihypertensives for more than five years, and 16 participants were using antihypertensive drugs from the class of calcium channel antagonists and 20 participants were using antihypertensive drugs from the class of angiotensin-converting enzyme inhibitors, all participants underwent venous blood sample collection for analysis of plasma concentrations of nitrate and $\mathrm{H}_{2} \mathrm{~S}$.

Regarding the general characteristics of the group, $69.4 \%$ of the patients were aged 60 years or more; $61.1 \%$ were female and $94.5 \%$ declared themselves white.

According to the figure below, the concentration of plasma NO was significantly higher in hypertensive patients that were taking angiotensin-converting enzyme inhibitors $(p<0.03)$ when related to the concentration in hypertensive patients using calcium channel antagonists.

${ }^{*}(p<0.03)$

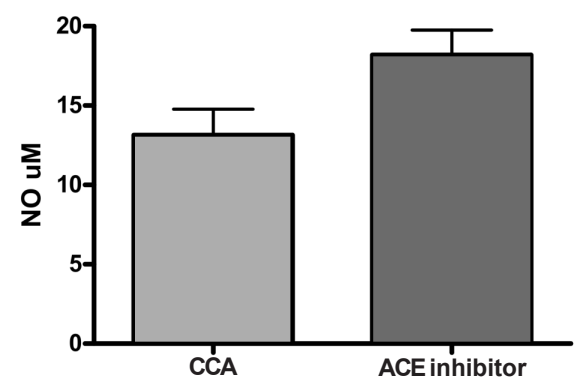

*Level of significance.

Figure 1 - NO plasma concentrations in hypertensive patients using calcium channel antagonists and inhibitors of angiotensinconverting enzyme - Ribeirão Preto, SP, Feb. to Nov. 2013.

The $\mathrm{H}_{2} \mathrm{~S}$ plasma concentration was significantly greater in hypertensive patients using calcium channel antagonists $(p<0.002)$ when related to the concentration in hypertensive patients using angiotensin-converting enzyme inhibitors, as shown in the figure below.

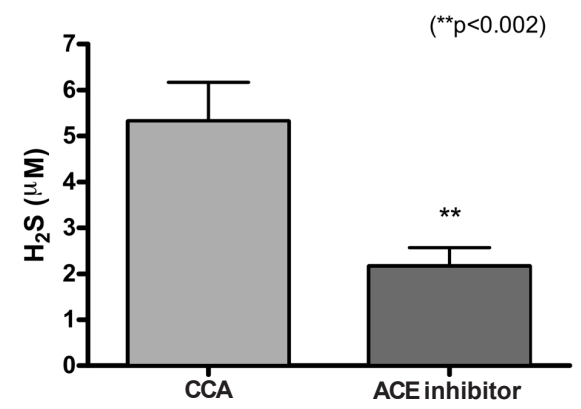

** Level of significance.

Figure $2-\mathrm{H}_{2} \mathrm{~S}$ plasma concentrations in hypertensive patients using calcium channel antagonists and inhibitors of angiotensinconverting enzyme - Ribeirão Preto, SP, Feb. to Nov. 2013.

In figures 3 and 4 we observed that there was no statistically significant association between plasma concentrations of nitrate and $\mathrm{H}_{2} \mathrm{~S}$ in hypertensive individuals treated with calcium channel antagonists $(p=0.09)$. We also did not observe statistically significant association between hypertensive individuals treated with angiotensin-converting enzyme inhibitors $(\mathrm{p}=0.32)$.

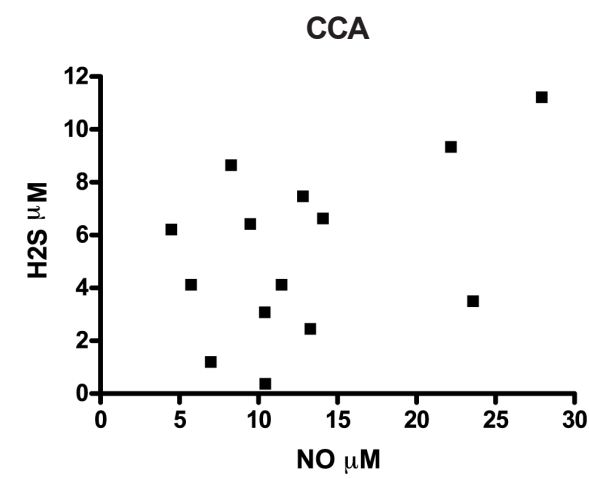

Figure 3 - Association between plasma nitrate and $\mathrm{H}_{2} \mathrm{~S}$ concentrations in hypertensive patients being treated with calcium channel antagonists $(p=0.09)$ - Ribeirão Preto, SP, Feb. to Nov. 2013.

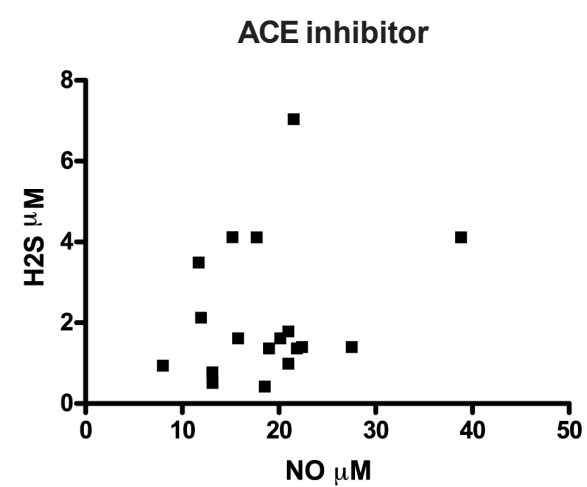

Figure 4 - Association between nitrate and $\mathrm{H}_{2} \mathrm{~S}$ concentrations in plasma in hypertensive patients with drug therapy with angiotensin-converting enzyme inhibitors $(p=0.32)$ - Ribeirão Preto, SP, Feb. to Nov. 2013. 


\section{DISCUSSION}

One of the competencies of the nursing staff is the administration of medicines. This brings up the need for a deep and up to date knowledge concerning pharmacology, so that practice is safe and based in scientific evidence. A study conducted with nurses in an intensive care unit had as objective to evaluate the knowledge of these professionals about drug interactions. The study demonstrated a relationship of right and wrong answers of approximately $50 \%$ of nurses ${ }^{(8)}$. Another study identified that nurses have insufficient knowledge in the practice of pharmacovigilance ${ }^{(9)}$.

These findings demonstrate the need to implement actions to raise the knowledge of nursing professionals about Pharmacology, ensuring quality and safety in care. The present study contributes to the advancement in the understanding of mechanisms of action of antihypertensive drugs and about gaseous mediators involved in blood pressure control, essential for clinical practice of the nurse.

A literature review carried out in Italy has recently pointed out that some antihypertensive drugs may improve Endothelial dysfunction, particularly calcium channel antagonists (CCA) on microcirculation, angiotensinconverting enzyme inhibitors (ACE Inhibitors) and AT-1 receptors antagonists, mainly on arterial vessels ${ }^{(10)}$. There is good evidence that Endothelial dysfunction is significantly associated with cardiovascular risk and can be considered as a barometer of the overall risk (the risk of risk factors) ${ }^{(11)}$. Consequently, its prevention and treatment are essential in reducing cardiovascular complications.

In our research, hypertensive patients that were using angiotensin-converting enzyme inhibitors (ACE Inhibitors) presented in larger NO plasma levels when compared to hypertensive patients using calcium channel antagonists. In a comparative study between angiotensin-converting enzyme inhibitors, calcium channel antagonists, beta blockers and diuretics on reactive hyperemia in patients with essential hypertension, found that the reactive hyperemia was significantly higher in the group treated with ACE Inhibitors, and may be due to the Nitric oxide elevation ${ }^{(12)}$.

Nitric oxide is among the most important vasodilating molecules, mostly in muscular arteries. It inhibits key events in the development of atherosclerosis, such as adhesion and platelet aggregation, leukocyte adhesion and migration, proliferation of smooth muscle cells ${ }^{(13)}$. Several studies are documenting that antihypertensive drugs medications contribute to the elevation of NO in plasma levels, such as Enalapril and Captopril (angiotensin-converting enzyme inhibitors) ${ }^{(14)}$ and the Nisoldipina (calcium channel antagonist) ${ }^{(15)}$.

Nitric oxide, carbon monoxide and hydrogen sulphide, belongs to gaseous transmitters that can be used therapeutically ${ }^{(16)}$. The complex mechanism of raising AP in hypertension by the deficiency of $\mathrm{NO}$ involves accentuation of the sympathetic system tonus, and renin angiotensin system and oxidative stress ${ }^{(17-18)}$.

Nitric oxide may spread from the endothelial cells to vascular smooth muscle cells and Guanylate Cyclase (GC) has been identified as an intracellular receptor of NO. Its activation leads to the release of the second messenger cyclic Guanosine monophosphate (cGMP) and to the activation of protein kinase (PK) G-dependent, resulting in decreased intracellular calcium concentration, followed by vasorelaxation. In addition, there are many other functions of the NO participating in the regulation of gene transcription, translation of mRNA and protein modification of several enzymes involved in mitochondrial respiration, mitogenesis and growth ${ }^{(19)}$. The signaling system of Nitric Oxide (NO) - Guanosine monophosphate (cGMP) (NO-cGMP) is a well-featured modulator of cardiovascular function, in general, and blood pressure, in particular ${ }^{(20)}$.

The renin-angiotensin-aldosterone system (RAAS) is also an important regulator of blood pressure and sodiumwater homeostasis. Multiple signalizing mechanisms regulate blood pressure. Both signaling and activity of NOcGMP, and RAAS play a central role in the homeostatic control of systemic arterial pressure ${ }^{(21)}$. Previous studies have shown that Angiotensin II raises the vascular production of reactive oxygen species (ROS) and thus reduces the bioavailability of $\mathrm{NO}$ and endothelium-dependent dilation ${ }^{(22)}$. Impaired endothelium-dependent relaxation results from decreased bioavailability of $\mathrm{NO}$, largely due to increased $\mathrm{O}_{2}$. This mechanism can be one of the explanations for raising of plasma levels in hypertensive patients using ACE Inhibitors in our study.

$\mathrm{ACE}$ inhibitors also affect kinins receptors. The B1 human receptor is directly activated by ACE Inhibitors for releasing NO most consistently in human endothelial cells $^{(23)}$, what can also explain the fact that the use of these drugs have in hypertensive plasma levels of the highest result found in this research. In addition, ACE Inhibitors therapy and low-calorie diet improve vasorelaxant response to acetylcholine ${ }^{(24)}$.

Our study was the first to measure plasma concentrations of $\mathrm{H}_{2} \mathrm{~S}$ in hypertensive patients and showed that plasma levels of gaseous transmitter were higher in subjects using calcium channel antagonists when compared to the group of hypertensive patients using angiotensin-converting enzyme inhibitors.

Calcium channel antagonists reduce the calcium entry channels of voltage-dependent L-type of muscle cells, vascular dilating coronary arteries and others. In addition, some CCA activate the NO endothelial synthase or has antioxidant properties, thereby increasing the bioavailability of NO. Particularly, dihydropyridine, can reverse the impaired endothelium-dependent vasodilation impaired in different places, including subcutaneous, epicardial, renal circulation and forearm. On forearm circulation, Nifedipine and Lacidipine can improve endothelial dysfunction, restoring the NO availability through a mechanism that is likely related to an antioxidant effect ${ }^{(25)}$.

In the field of studies of $\mathrm{H}_{2} \mathrm{~S}$, Wilinski and colleagues at the Jagiellonian University in Poland have shown the greater impact of a variety of pharmacological agents on the production of endogenous $\mathrm{H}_{2} \mathrm{~S}$ and postulated the drugmodulatory role of $\mathrm{H}_{2} \mathrm{~S}$ in this scenario ${ }^{(26)}$. Drugs that alter 
the channel sulfidation, mediated by $\mathrm{H}_{2} \mathrm{~S}$ can be therapeutic agents and effective in the treatment of hypertension ${ }^{(27)}$.

In addition to $\mathrm{NO}, \mathrm{H}_{2} \mathrm{~S}$ has also been identified recently as a gaseous transmitter. By direct action on the $\mathrm{K}_{\text {ATP }}$ channels of smooth muscle cells, it has vasorelaxant properties. It has the potential to react with metal ions $(\mathrm{Cu}, \mathrm{Fe}$, $\mathrm{Zn}$ ) in metalloprotein. The angiotensin-converting enzyme (ACE), responsible for vasoconstriction, is an enzyme that contains zinc. The $\mathrm{H}_{2} \mathrm{~S}$ shows an inhibitory action on ACE activity in human surface endothelial cells, by interfering with zinc in the active center of this enzyme. So, next to the well-known influence of $\mathrm{H}_{2} \mathrm{~S}$ in $\mathrm{K}_{\text {ATP }}$ channels in smooth muscle cells, the direct inhibitory effect on ACE can contribute to the vasorelaxant effect of $\mathrm{H}_{2} \mathrm{~S}$ in the vasculature, reducing the production of angiotensin II and inhibiting the degradation of bradykinin ${ }^{(28)}$. The decrease of $\mathrm{H}_{2} \mathrm{~S}$ under hyperglycemic condition leads to an imbalance between oxidative and reductive species. The increase in oxidative species result in activation of the renin angiotensin system, which, in turn, contributes to the pathogenesis of renal dysfunction ${ }^{(29)}$.

The $\mathrm{H}_{2} \mathrm{~S}$ inhibits the activity of plasma renin and diminish angiotensin II production in plasma, thus generating preventive and therapeutic effects on renovascular hypertension in rats ${ }^{(30)}$. These data suggest that $\mathrm{H}_{2} \mathrm{~S}$ plays an anti-hypertensive role not only for its action on the $\mathrm{K}_{\text {ATP }}$ channels of smooth muscle cells, but also to suppress the activity of the renin-angiotensin-aldosterone system. These findings may provide a therapeutic potential in the treatment of renovascular hypertension, suppressing the excessive activity of RAAS.
Our results suggest that CCA improve vascular function through raising plasma levels of $\mathrm{H}_{2} \mathrm{~S}$ in hypertensive patients. This new mechanism, not related to its action on the $\mathrm{K}_{\mathrm{ATP}}$ channels of smooth muscle cells and inhibition of ACE, may also explain the beneficial effects of CCA reported in the clinical literature.

We can cite as a limiting factor of the study the difficulty of finding hypertensive patients using antihypertensive monotherapy, since the vast majority of medicinal requirements includes the combination of different antihypertensive agents.

\section{CONCLUSION}

The findings of this research suggest that pharmacotherapy with ACE Inhibitors and CCA in hypertensive subjects can alter circulating concentrations of gaseous mediators, such as $\mathrm{NO}$ and $\mathrm{H}_{2} \mathrm{~S}$, noticing no association between these two mediators during treatments and these medications have as additional action mechanism the improvement of endothelial dysfunction by raising plasma levels of vasodilatory substances, which collaborates with their antihypertensive effects.

The research contributes to the advancement in knowledge of ACE Inhibitors and CCA mechanisms of action and their relationship with plasma concentrations of gaseous mediators involved in the control of blood pressure. This information is relevant to the practice of nurses and their team, who cannot work in health institutions with the general knowledge of drugs based on empiricism. Thorough education of drug therapy should be part of nurses training and improvement for a reasoned and safe practice.

\section{RESUMO}

Objetivo: Avaliar o efeito do uso de anti-hipertensivos pertencentes às classes medicamentosas antagonistas de canais de cálcio e inibidores da enzima conversora de angiotensina nas concentrações plasmáticas de ácido sulfídrico e óxido nítrico em portadores de hipertensão arterial sistêmica. Método: Estudo transversal com abordagem quantitativa realizado com hipertensos em uso de antihipertensivos das classes inibidores da enzima conversora de angiotensina ou antagonistas dos canais de cálcio. Resultados: Verificou-se que a concentração de óxido nítrico plasmático foi significativamente maior em hipertensos que estavam em uso de inibidores da enzima conversora de angiotensina $(\mathrm{p}<0.03)$ e que a concentração de ácido sulfídrico plasmático foi significativamente maior em hipertensos em uso de antagonistas dos canais de cálcio $(\mathrm{p}<0.002)$. Conclusão: Os achados sugerem que essas medicações possuem como mecanismo de ação adicional a melhora da disfunção endotelial por elevar os níveis plasmáticos de substâncias vasodilatadoras.

\section{DESCRITORES}

Hipertensão; Óxido Nítrico; Sulfeto de Hidrogênio; Anti-Hipertensivos.

\section{RESUMEN}

Objetivo: Evaluar el efecto del uso de antihipertensivos pertenecientes a las clases medicamentosas antagonistas de canales de calcio e inhibidores de la enzima convertidora de angiotensina en las concentraciones plasmáticas de ácido sulfhídrico y óxido nítrico en portadores de hipertensión arterial sistémica. Método: Estudio transversal con abordaje cuantitativo realizado con hipertensos que toman antihipertensivos de las clases de inhibidores de la enzima convertidora de angiotensina o antagonistas de los canales de calcio. Resultados: Se verificó que la concentración de óxido nítrico plasmático fue significativamente mayor en hipertensos que estaban usando inhibidores de la enzima convertidora de angiotensina $(\mathrm{p}<0.03)$ y que la concentración de ácido sulfhídrico plasmático fue significativamente mayor en hipertensos en uso de antagonistas de los canales de calcio ( $<<0.002)$. Conclusión: Los hallazgos sugieren que dichos fármacos tienen como mecanismo de acción adicional la mejora de la disfunción endotelial al elevar los niveles plasmáticos de sustancias vasodilatadoras.

\section{DESCRIPTORES}

Hipertensión; Óxido Nítrico; Sulfuro de Hidrógeno; Antihipertensivos 


\section{REFERENCES}

1. Mendes EV. O cuidado das condições crônicas na atenção primária à saúde: o imperativo da consolidação da estratégia da saúde da família. Brasília: Organização Pan-Americana da Saúde; 2012

2. Roger VL, Go AS, Lloyd-Jones DM, Adams RJ, Berry JD, Brown TM, et al. Heart disease and stroke statistics--2011 update: a report from the American Heart Association. Circulation. 2011;123(4):e18-e209.

3. Pereira AC, Paulo M, Araújo AV, Rodrigues GJ, Bendhack LM. Nitric oxide synthesis and biological functions of nitric oxide released from ruthenium compounds. Braz J Med Biol Res. 2011;44(9):947-57.

4. Wang R. Hydrogen sulfide: a new EDRF. Kidney Int. 2009;76(7):700-4.

5. Liu YH, Lu M, Hu LF, Wong PT, Webb GD, Bian JS. Hydrogen sulfide in the mammalian cardiovascular system. Antioxid Redox Signal. 2012;17(1):141-85.

6. Law MR, Morris JK, Wald NJ. Use of blood pressure lowering drugs in the prevention of cardiovascular disease: meta-analysis of 147 randomised trials in the context of expectations from prospective epidemiological studies. BMJ. 2009;338:b1665.

7. Sociedade Brasileira de Patologia. Recomendações da Sociedade Brasileira de Patologia Clínica/Medicina Laboratorial para coleta de sangue venoso. $2^{\mathrm{a}}$ ed. Barueri; 2010.

8. Faria LMP, Cassiani SHB. Interação medicamentosa: conhecimento de enfermeiros das unidades de terapia intensiva. Acta Paul Enferm. 2011;24(2):264-70.

9. Alan S, Ozturk M, Gokyildiz S, Avcibay B, Karataş Y. An evaluation of knowledge of pharmacovigilance among nurses and midwives in Turkey. Indian J Pharmacol. 2013; 45(6):616-8.

10. Ghiadoni L, Taddei S, Virdis A. Hypertension and endothelial dysfunction: therapeutic approach. Curr Vasc Pharmacol. 2012;10(1):42-60.

11. Flammer AJ, Anderson T, Celermajer DS, Creager MA, Deanfield J, Ganz P, et al. The assessment of endothelial function: from research into clinical practice. Circulation. 2012;126(6):753-67.

12. Higashi Y, Sasaki S, Nakagawa K, Ueda T, Yoshimizu A, Kurisu S, et al. A comparison of angiotensin-converting enzyme inhibitors, calcium antagonists, beta-blockers and diuretic agents on reactive hyperemia in patients with essential hypertension: a multicenter study. J Am Coll Cardiol. 2000;35(2):284-91.

13. Edwards G, Feletou M, Weston AH. Endothelium-derived hyperpolarising factors and associated pathways: a synopsis. Pflugers Arch. 2010;459(6):863-79

14. Kim JH, Kim H, Kim YH, Chung WS, Suh JK, Kim SJ. Antioxidant effect of captopril and enalapril on reactive oxygen species-induced endothelial dysfunction in the rabbit abdominal aorta. Korean J Thorac Cardiovasc Surg. 2013;46(1):14-21.

15. Wei D, He WY, Lv QZ. Effect of nisoldipine and olmesartan on endothelium-dependent vasodilation in essential hypertensive patients. CNS Neurosci Ther. 2012; 18(5):400-5.

16. Ostrowski RP, Pucko EB. Research of medical gases in Poland. Med Gas Res. 2013; 3(1):17.

17. Dillenburg DR, Mostarda C, Moraes-Silva IC, Ferreira D, Bós DS, Duarte AA, et al. Resveratrol and grape juice differentially ameliorate cardiovascular autonomic modulation in L-NAME-treated rats. Auton Neurosci. 2013;179(1-2):9-13.

18. Nakmareong S, Kukongviriyapan U, Pakdeechote P, Kukongviriyapan V, Kongyingyoes B, Donpunha W, et al. Tetrahydrocurcumin alleviates hypertension, aortic stiffening and oxidative stress in rats with nitric oxide deficiency. Hypertens Res. 2012;35(4):418-25.

19. Forstermann U, Sessa WC. Nitric oxide synthases: regulation and function. Eur Heart J. 2012;33(7):829-37, 837a-837d.

20. Aroor AR, Demarco VG, Jia G, Sun Z, Nistala R, Meininger GA, et al. The role of tissue Renin-Angiotensin-aldosterone system in the development of endothelial dysfunction and arterial stiffness. Front Endocrinol (Lausanne). 2013;4:161.

21. Ruilope LM. Hypertension in 2010: blood pressure and the kidney. Nat Rev Nephrol. 2011;7(2):73-4.

22. Garrido AM, Griendling KK. NADPH oxidases and angiotensin II receptor signaling. Mol Cell Endocrinol. 2009;302(2):148-58.

23. Stanisavljevic S, Ignjatovic T, Deddish PA, Brovkovych V, Zhang K, Erdös EG, et al. Angiotensin I-converting enzyme inhibitors block protein kinase C epsilon by activating bradykinin B1 receptors in human endothelial cells. J Pharmacol Exp Ther. 2006;316(3):1153-8.

24. Nevelsteen I, Van den Bergh A, Van der Mieren G, Vanderper A, Mubagwa K, Bult H, et al. NO-dependent endothelial dysfunction in type ii diabetes is aggravated by dyslipidemia and hypertension, but can be restored by angiotensin-converting enzyme inhibition and weight loss. J Vasc Res. 2013;50(6):486-97.

25. Tang EH, Vanhoutte PM. Endothelial dysfunction: a strategic target in the treatment of hypertension? Pflugers Arch. 2010;459(6):995-1004.

26. Wiliński B, Wiliński J, Somogyi E, Góralska M, Piotrowska J. Ramipril affects hydrogen sulfide generation in mouse liver and kidney. Folia Biol (Krakow). 2010; 58(3-4):177-80.

27. Zhang Y, Tang ZH, Ren Z, Qu SL, Liu MH, Liu LS, et al. Hydrogen sulfiede, the next potent preventive and therapeutic agent in aging and age-associated diseases. Mol Cell Biol. 2013;33(6):1104-13.

28. Laggner H, Hermann M, Esterbauer H, Muellner MK, Exner M, Gmeiner BM, et al. The novel gaseous vasorelaxant hydrogen sulfide inhibits angiotensin-converting enzyme activity of endothelial cells. J Hypertens. 2007;25(10):2100-4.

29. Xue H, Yuan P, Ni J, Li C, Shao D, Liu J, et al. H(2)S inhibits hyperglycemia-induced intrarenal renin-angiotensin system activation via attenuation of reactive oxygen species generation. Plos One. 2013;8(9):e74366.

30. Lu M, LiuYH, Goh HS, Wang JJ, Yong QC, Wang R, et al. Hydrogen sulfide inhibits plasma renin activity. J Am Soc Nephrol. 2010;21 (6):993-1002. 